\title{
Finance, Market, Globalization: Lessons from the 2007-09 Crisis
}

\author{
SALVATORE ROSSI \\ Bank of Italy*
}

\begin{abstract}
Never before has finance been regarded with the suspicion of these past three years. Yet money and credit are part of what enabled human beings to overcome the barbarism of immanence, the savagery of a life ruled by consumption for survival. The critical rethinking of finance involves the very notion of market economy and the globalized dimension it has reached. Who failed in this crisis, the State or the Market? The State, although by virtue of a paradox. Is globalization the culprit? No. A different financial system must emerge from the 2007-09 crisis: freed from the "idolatry of laissez-faire", but not thrown back into obsolete technologies or permanently restrained by anachronistic "real socialism" bridles.
\end{abstract}

Keywords: Financial Crises, Financial Systems, Bank Supervision, Crisis Management, Liberalism, Globalization, Regulation

JEL Classifications: E02, E32, E65, F3, G01, G2, G21, G28

\section{Introduction}

Never before has finance been regarded by people all over the world with the suspicion of these past three years. In the United States of America, in particular, the system made up of financial intermediaries and their regulators and supervisors laid itself open to severe public censure, that rapidly spread throughout the globe. The critical rethinking of finance is involving the very notion of market economy and the globalized dimension it has reached in recent years.

Finance, the market and globalization are at risk of being demonized, even by moderate observers of economic affairs. Moralistic invectives, however, are always misleading. What I would like to do instead in this paper is to develop a some more balanced analysis, based on sensible economics.

\footnotetext{
* Managing Director, Economics, Research, International Relations. This paper is based on the Rimini Lecture in Economics and Finance delivered in Rimini, March 2009. It elaborates on S. Rossi, "Miseria e nobiltà della finanza", in: Il Mulino, 6/2008, and on the comments posted on www.voxeu.org on 20 November 2008, 28 January 2009, and 25 February 2009. My thanks to Magda Bianco, Alfredo Gigliobianco, Marco Magnani, Giuliana Palumbo, Fabrizio Saccomanni and Ignazio Visco for their useful comments on earlier drafts. Errors and the opinions expressed are entirely my own responsibility and in particular do not reflect the views of the institution to which I belong.

(C) 2010 Salvatore Rossi. Licensed under the Creative Commons Attribution Noncommercial Licence 3.0.Available at http://rofea.org.
} 


\section{Finance: instrumentum diaboli?}

At its core, finance is first and foremost a mechanism for shifting purchasing power over time. Giving credit is an ancient human activity. If A produces a surplus with respect to his needs and is far-sighted, he gives it to B, who is short of it. B promises to return it after a specified time, increased by an amount that rewards A's sacrifice of deferred gratification. Already embedded in this ancient mechanism is one traditional motive for distrusting those who engage in financial activity. A is in any event open to the suspicion of immoral conduct, irrespective of the position in which B finds himself: if B is only a carefree grasshopper who doesn't plan for tomorrow, then the disagreeable ant A will encourage his spendthrift ways for his own personal profit; if B is in a state of genuine need, worse yet, A will basely exploit him today to get rich tomorrow. It is well known how in some human communities, at certain times in the past but also today (for example in the Islamic world), charging interest on loaned money is forbidden by either law or religion.

The very concept of money was probably devised at the dawn of humanity along with that of credit, and perhaps even at its service, as a means of transferring spending power over time by detaching it from any specific physical good. Money later supplanted credit as a source of symbols in the popular imagination and it too acquired negative connotations. A little over a century ago, the German philosopher Georg Simmel (1900) conducted a systematic inquiry into money and its role in the life of modern man; he commented on the devaluation of life itself to money and of man's value to monetary value. There are echoes of the Marxian concept of alienation in his thinking; more generally, there is the anguish of the humanist who struggles to lend logical and historical meaning to what he perceives as the unstoppable desertification of the human condition.

Yet money and credit are part of what has enabled human beings to free themselves from the barbarism of immanence, from the savagery of a life ruled by the consumption for survival, which is spent in an instant. They teach man to think about the unfolding of time and they do so by appealing to the most powerful of all psychological levers, that of desire and need. Learning how to project a desire into the future or to predict a requirement is a fundamental step in evolution. It pushes people to design a method for satisfying future desires or needs, and that method is saving. Limiting oneself to saving alone - simply burying nest-eggs underground in anticipation of the day they will be needed - is a method that is possibly useful to the individual and useful to society only as a sum of individuals. If, however, everyone profitably invested their own savings by lending to one another, both the personal (when the investment is interest-bearing) and the social utility would be multiplied, because two entities would benefit from the loan rather than one. Individual saving was already implicit even in the archaic economy of pure hunting and gathering; social saving and investment became important as the economy shifted to agricultural production and then to the industrial and post-industrial models. In economies of this kind, credit meets two needs 
simultaneously: that of investors who have in mind their future consumption (needs-desires) and that of those who, on the other hand, require additional immediate purchasing power. This second group might be motivated by the mere urge to consume, but they might also be motivated - and this is the most interesting case from a social point of view - by the desire to increase their own productive capacity and therefore by a plan that is equally far-sighted and future-oriented. In this case the spending power would be transferred from those who at that moment do not have a business idea to exploit, to those who do.

In a monetary economy, finance is what makes the saving-credit-investment gears turn. It consists of markets and intermediaries whose job is to assure the optimal allocation of resources and risks.

As is readily appreciable from these sketchy considerations, finance is one of humanity's great intellectual achievements. Yet it does not enjoy the universal admiration accorded to such other intellectual watersheds as the wheel or the number zero. The problem is that everybody can use the wheel and the number zero profitably, easily and naturally, while by definition finance creates a conflict of interest between two major, and equally deserving, categories: lenders and borrowers. The first group will want to see high interest rates and broad guarantees, be they real collateral or based on reputation, for the restitution of the loan. The second group will want low interest rates and the possibility to provide the minimum guarantee.

The unalterable fact that the objectives of these two groups are, at least in part, conflicting leads to tensions being inevitably offloaded onto professional intermediaries, and on the public authorities that influence market interest rates and supervise the activity of intermediaries. Professional financial operators always run the risk of being seen as parasites who are happy to sit back and let others toil - the people who produce tangible goods and save up to ensure that they can retire in peace - before fleecing them mercilessly.

It must be acknowledged that the victims of this prejudice often do little to dispel it; indeed, at times their conduct seems designed to lend it credence. Evident examples of this are to be found in the last global financial crisis.

\section{Should we Replace the Market with the State?}

To put it in factual terms, who has failed in this crisis, the State or the Market? I would dare to argue that it was more a State failure, paradoxically.

One firmly established conclusion after centuries of economic science is that the market must be "regulated" or it is no market. If the government practiced absolute laissez-faire, the free competitive market could not last, it would be strangled by the natural tendency of operators to undermine competition or, alternatively, to embark on an explosive competitive path. This is a law of nature, a sort of economic entropy. The pure competitive market is the optimal regime from the standpoint of "buyers," i.e. the community as a whole, but the worst 
possible for "sellers," a powerful minority constantly trying hard to oppose it. Such a market is a limiting condition that one may seek to approximate and more or less maintain only by virtue of unflagging effort on the part of the public authorities. Clear, comprehensive, specific rules are essential, as well as farsighted, attentive regulators and supervisors who cannot be captured by "sellers". Regulation and supervision must obviously be efficient: the burden of the regulatory apparatus that inevitably weighs on firms ought to be non-distorting, nonbureaucratic and light. But we cannot do without it.

This forms the essence of what I consider the most advanced contribution of liberalism to economic thought. Nobody should confuse the great principles of liberty with the arbitrariness of complete laissez-faire. Eighty years ago, an Italian champion of liberalism in politics and a neatly pro-free-market economist, Luigi Einaudi, wrote:

The maxim of economic liberalism (is) taking on a third - I would call it a religious meaning. In this interpretation, "economic liberals" are those who accept the maxim of laissez-faire, laissez-passer almost as if it were a universal principle. (...) The whole subsequent history of the doctrine demonstrates that economic science (...) has nothing to do with the religious conception of economic liberalism. ${ }^{1}$

The "religious" notion that Einaudi so scathingly stigmatized was resuscitated in the second half of the century just past, as the consequence of a debate on the foundations of public economy. The standard theory that saw regulation as fundamental to the public interest (a legacy of the economists who worked between the 1930s and the 1960s) rested on two assumptions: a) if left to themselves, markets often "fail” due to monopoly or externalities; b) government is generally well-intentioned and capable of correcting market failures by regulation. Since the 1960s these assumptions have undergone increasing criticism, giving way to an alternative view, based on three postulates: 1) markets themselves or, at the most, private orderings, can virtually remedy all market failures, with no need for government intervention; 2) in the tiny number of cases in which markets do not work correctly, civil courts are sufficient in order to resolve the disputes; and 3) even if both markets and courts should somehow fail to solve the problem, certainly governments alone would never succeed, as they are necessarily incompetent, possibly corrupt, and "captured" by the very interests they are supposed to regulate, therefore they can only make matters worse. ${ }^{2}$

The schools of thought that back this critique are unquestionably among the cornerstones of twentieth-century economics. However, such critique has in turn been criticized both theoretically and empirically. On the empirical side, in particular, the strident contrast

\footnotetext{
${ }^{1}$ L. Einaudi (1931), "Dei diversi significati del concetto di liberismo economico e dei suoi rapporti con quello del liberalismo” in B. Croce and L. Einaudi, Liberismo e liberalismo (Ricciardi: Milan and Naples, 1988). English translation in Luigi Einaudi, Selected Economic Essays (Palgrave Macmillan: Basingstoke and New York, 2006), pp. 75-76.

${ }^{2}$ This critique is ordinarily associated with the Chicago School of Law and Economics and with such economists as Ronald Coase, George Stigler and Michael Posner. This thumbnail account of the debate is drawn from A. Shleifer (2005).
} 


\section{ROSSI Lessons from the Ongoing Crisis}

between the doctrine's precepts and the reality of a world at once far wealthier and far more regulated than a hundred years ago has been pointed out (Shleifer, 2005). However, over the last twenty years, especially in Britain and America, these premises have been used to forge a sort of religious dogma, as Einaudi understood it, and the policies today under indictment stemmed from that very religion. The global financial crisis of the past three years turns empirical evidence totally against it.

The US machinery of regulation and oversight over financial markets and intermediaries has been for decades feeble and ineffective. The most innovative and dynamic segments of finance (investment banks, hedge funds, private equity funds, the CDS market, the ABS market and more) have escaped oversight altogether and so they have operated in a state of total self-regulation. Supervision over the rest of the system was pulverized in scores of agencies, hard to coordinate, each seeing only a few pieces of the puzzle. What made regulation and oversight in the US so wrecked? A sequence of conscious political choices, dictated by ideological fury. A false ideology, indeed: the laissez-faire fundamentalism that has dominated the scene in all these years pretended to be pro-market, but in reality it bore no relationship with the great principles of liberalism.

The fundamental problem underlying the crisis has in fact been one of rules and their effective application. Often enough, the heated polemics between advocates and adversaries of the "free market" actually lack a point of contention. Indeed, they may undergo a complete role reversal. The laissez-faire fundamentalists may paradoxically be seen as State interventionists, in that they want the government, allying with vested interests, to purposely deprive the competitive market of the air it breathes (i.e. rules and supervision), in order to promote the wealth of a tiny privileged caste at the entire national community's expense. If this view is correct, we can, by a twist of language, call it a State failure: a failure by inaction, rather than excessive action, consisting in the refusal to see, to counter or to correct an evident series of market failures.

\section{Globalization: the Accomplice?}

In the frenzied hunt for a scapegoat during this delicate conjuncture, there has been no lack of anathemas proclaimed against globalization as the root of all ills now afflicting advanced economies.

In the past years globalization has attracted contrasting value judgments about its actual or potential effects on the wellbeing of all the people involved. Detractors and enthusiasts have squared off for some time, but the former have been rapidly gaining ground since the outbreak of the financial crisis.

Concerning globalization's effects on the emerging countries, prominent in the ranks of the detractors are those who contend that globalization only brings ecological disaster, exploitation and loss of identity. No doubt this vision has suggestive power and some aspects 
deserving consideration, but it is often reduced to caricature and, at any rate, is largely not susceptible to testing with the instruments of social science, because it is couched in mainly ideological, aesthetic and moral terms. On the contrary, the defenders of globalization see it as the opportunity to raise immense numbers of human beings out of extreme poverty and historical neglect. This apparently optimistic, historicist vision rests nonetheless on vast and solid foundations. For example, in the emerging regions of the Far East, per capita income grew by more than 7 per cent in the first half of this decade and in China by 8 or 9 per cent. The figures are lower in India and Latin America, but still indicate an ascent from backwardness. It is estimated that half a billion people in the world have been liberated from dire poverty in the last twenty years, a period during which the planet's population increased by one and a half billion! A vast body of highly sophisticated empirical research has convincingly established that there is a positive link between globalization and the acceleration of economic growth in the emerging countries.

As to globalization's impact on the advanced countries, the traditional forces of "freetraders" and "protectionists" are arrayed against each other. The advocates of free trade represented a large majority as long as things were going at least tolerably well. Their position rested on some of the most analytically clear-cut and empirically well-established results in all of economic science, which holds that free trade in goods and services makes all the participants better off than they could be in a situation in which international trade is somehow and to some extent limited. The contemporary Italian history is a good case in point: in the 1950s the courageous decision of the governments of the day to bring Italy into the European Common Market, dismantling the tariff barriers that had been erected to defend a weak industry, was a powerful engine of development and the main cause of Italy's "economic miracle" of those years. And there was no lack of protectionists even then, especially in private industry!

Since 2007, however, the advocates of free trade have been on the defensive and the protectionists are making headway. Even earlier, it had been observed in the advanced countries that the competition of the emerging countries was throwing whole industrial sectors into crisis, especially the "traditional" industries of textiles and clothing or light machinery, manufacturing operations easily mastered even by a Chinese peasant recently turned factory worker, whose wages at the current exchange rate are a twentieth of a German or Italian worker's. In these industries the incidence of labour costs on sales revenues is as high as 50 per cent, and under such circumstances competition is plainly unsustainable. Public opinion is further chafed by the evidence of unfair competitive practices, such as product counterfeiting, or labour malpractices, such as the use of child labour, that are considered immoral in the advanced countries. Free-traders have nonetheless a powerful argument on their side: in earlier times, the argument goes, we were the Chinese. You cannot stop the progress of those who are trailing and striving to catch up. The advanced countries must leave 


\section{ROSSI Lessons from the Ongoing Crisis}

the easier phases of production to the emerging countries and specialize in the more complex ones, where the use of technology, the know-how and skills of labour (human capital) and organizational and entrepreneurial knowledge count more. In this way the jobs inevitably lost in the abandoned sectors will be rapidly replaced in the new sectors of specialization. The only worry will be the transition, which will call for policies to safeguard the standard of living of the households in trouble, to retrain workers for new areas of production; in sum, a dose of sound and well targeted welfare policies. This reassuring vision held up rather well in general opinion until the outburst and the subsequent development of the financial crisis.

Complaints then tended to be mixed up: the Chinese are waging unfair competition against me, I find a toxic asset in my securities portfolio that I didn't even know I had, my bank is making trouble about giving me more credit since it is unable to procure liquidity in a global market paralyzed by mutual distrust... All this, most people thought, surely had something to do with globalization.

The problems are serious and real, but the target is too generic to be useful. Globalization is a set of heterogeneous phenomena involving various aspects: real economy (produced and traded goods and services), financial economy, people, their ideas and their knowledge. These aspects all have one characteristic in common: the heightened mobility, cross-border as well as domestic, made possible by the revolution in ICTs and the innovations that have followed in its wake. Technology, indeed, is the prime mover, even though the trade and financial liberalization policies adopted in many countries in the 1990s assisted the process.

As a matter of fact, globalization and innovative finance are two sides of the same coin, minted by technological innovation. Technological progress in itself is neither good nor bad, neither efficient nor inefficient. It represents an opportunity for individuals, societies and economies; it must be understood and governed, not permitted to overwhelm us, but it cannot be stopped. It would be futile to try and halt or reverse technological innovation and, even if such an attempt succeeded, it would condemn those who made it to backwardness and marginality.

\section{The Baedeker of the 2007-09 Financial Crisis}

Having thus acquitted all the accused on the charge of staging a plot against mankind, we still need to understand what happened. Let us make a cursory review of the main events.

Prologue. For at least a decade and a half, the entire world had been inundated by liquidity. Total world liquidity is hard to define even just as a concept, harder still it is to measure; yet the intuitive notion and the countless estimates of it all seem to point to that same conclusion - a flood of liquidity - although there is no unanimous agreement on its causes. Some observers have blamed a global saving glut over investment (Bernanke, 2005), itself traced to a variety of causes, such as the lack of social security in the emerging economies, which leads households to save much of their rising disposable income, or the 
uncertainty that heightened competition has generated among firms. But many do concur that the bulk of the increase in liquidity stemmed from the monetary policy conducted in the United States (Adrian and Shin, 2008).

This policy was impelled by a worthy reason. The Federal Reserve had sensed, in the mid1990s, that the technological paradigm was changing and that this would shift the trend of productivity upward. Accordingly, the monetary policy had to adapt to a potential output growth that was likely to be much more robust than in the past. Unhappily this stance, which was bold and timely when undertaken, was kept for too long, even in years when the propulsive force of the new technology was fading; it was sustained by a true antirecessionary obsession, in the face of risky shocks such as11/9. The situation was aggravated by a dramatic fall in American households' propensity to save.

Meanwhile the Bank of Japan too had begun to create super-abundant liquidity in the effort to rescue an economy mired in its "lost decade” of the 1990s. There was a deflationary situation, provoked by the crash in property prices, which had reached irrationally high levels. In a deflation, consumer prices actually fall, but people still don't spend; they are gripped by fear of the future, and economic activity stagnates or contracts. The situation in Japan was compounded by serious structural problems: the great corporations were in the throes of changes in governance and organization that were repeatedly promised but not actually carried out by the old business class. Banks were slow in putting their accounts in order, hiding their bad loans under the rug. The Bank of Japan's decision to react by creating money probably came too late, so that a truly massive dose was needed. This liquidity too ended up overflowing national borders.

Because of the size of the US and Japanese economies, the liquidity flood had repercussions on a world scale. But it did not have the traditional effect of accelerating consumer price inflation, thanks to the credibility that central banks had meanwhile acquired. Instead, it roamed the US and the world in search of promising investment opportunities. First, it found the "dotcoms", then the oldest and most traditional of investments - real estate. The quantity of money that poured into real estate markets around the world rapidly inflated property prices, which soared exceptionally high in the United States, where the trend was fuelled by a populist housing policy.

The climax. In the end, this bubble too burst. But this one had a poisonous epilogue: the mortgages to the wretches-who-can-hardly-repay (plain English for the euphemistic "subprime borrowers"), granted by the million in the United States, with unprecedented loanto-value ratios and teasing conditions. Moreover, these mortgages were securitized, i.e. sliced into tiny pieces and worked into financial sausages that were resold all around the world, each with its own hidden toxic germ, to famished investors, some unaware and others less so. For years, in fact, the banks had taken to transforming their claims on households and firms into pieces of paper and selling them in the market to others, typically large non-bank financial 


\section{ROSSI Lessons from the Ongoing Crisis}

operators, who thus took on all the risk. The latter, in turn, could repeat the operation, slicing up the sausages anew and redistributing them to other buyers.

Securitization has been an attempt to improve the financial system. The idea is to distribute credit risk as widely as possible, though leaving it always in the hands of professional investors, in order to make banks' financial resources available for further lending to the economy. Noble intentions, to be sure, but undone by a reality that got the better of these sorcerer's apprentices and exploded the entire system: just to mention one problem, it turned out ex post that most of the securities based on mortgages had not been diffused outside the originating banks, but had remained in the hands of "special vehicles" emanating from those same banks, so that the risk was still concentrated there; it had only been made invisible, put off-balance-sheet.

The "originate to distribute" model of banking business changes the nature of banking, practically eliminating the very raison d'être of intermediaries whose specialty is selecting creditworthy entrepreneurs, deploying their superior ability to gather and process information on firms and their business. For if risk changes hands, the incentive to perform this selection properly evaporates, while those who take it on, through the market, in homeopathic doses, lack sufficient incentive to sustain the costs of constant monitoring final debtors' health.

Towards an epilogue? The crisis quickly led to a global collapse of confidence, as financial operators all over the world began to mistrust one another owing to everyone's continuing lack of information on how many toxic sausages were being carried on everyone else's balance sheet, directly or through "shadow" partners. With the outbreak of the epidemic, the interbank, money, and credit markets were semi paralyzed or severely impaired. Some major banks suffered huge losses. Some had to be bailed out with public money, others were bought up by competitors at fire sale prices, others still were simply declared bankrupt. This fuelled further uncertainty and fear. It was as if the entire audience in a cinema were suddenly blindfolded. For fear of tripping over a neighbour, they would all sit tight, at least for a while. Then, if someone were to cry "Fire!”, mass panic and stampede would kill many - and maybe there was no fire after all.

The risk was that the paralysis in lending between banks could extend to the rest of their balance sheets. This would damage producers, whose sources of credit dry up. A credit crunch is the prime way in which real economies feel the repercussions of a financial crisis, and it did happen, to some extent, despite the activism of central banks in taking the place of the interbank market.

\section{Out of the Emergency: Restoring the Credit Market}

A recessionary spiral gathered strength all over the world after the Lehman Brothers collapse. To stop it, we needed first to get credit to flow again in the arteries of our economies. This

was an absolute precondition: no fiscal package supporting aggregate demand, however big 
and well conceived, could work unless the heart attack that had stricken the global financial system was cured first. On this, there was a vast consensus of opinion.

Credit was rarefied because several banks had a structural balance-sheet imbalance: in the last 5 to 10 years, more in some countries and less in others, they had borrowed too much relative to their capital, and used too much of these borrowed resources to buy assets that were distressed.

Such banks had to deleverage. But the uncertainty surrounding the "true" value of their assets was keeping private investors from holding those banks' shares, lending them money, or purchasing their assets. So the only way they could deleverage was to cut lending to the economy. This risked to worsen the recession, in turn increasing the "bad" portion of banks' assets, in a downward spiral. Clearly, the public sector had to step in. How? Here opinions varied.

There were two basic schools of thought. One said that government should intervene on the banks' asset side by buying distressed assets. The other countered that government should rather intervene on the liability side, recapitalizing the banks. The former posed one tremendous problem: how to price assets for which a market no longer existed. The latter posed a problem of governance (moral hazard) that was no less serious.

In the United States, the 2008 TARP I program took the first route: to buy toxic assets, setting prices through reverse auctions. This soon proved technically unfeasible, so the program was re-oriented towards the other aim, i.e. recapitalizing banks (TARP II). To some extent that was done, through preferred shares so the control/management of the banks was not called into question. This occasionally sparked public outrage, as people saw a lot of taxpayers' money flowing into the pockets of banks' shareholders and managers without any apparent success in unblocking the credit market or halting the recession.

Some variations on such basic approaches were also proposed. Here are two relevant examples.

Ricardo Caballero (2009) argued that the uncertainty ravaging credit and financial markets was of a Knightian type, i.e. not amenable to probabilistic assessment: in these circumstances each individual reacts to the worst-case scenario, that is in general different for the two sides of any transaction, thus leading to an extremely risk-averse behaviour and to a very inefficient double (or multiple) counting and hoarding of liquidity. Hence the main - though not exclusive - role of government should be to provide explicit and systemic insurance, at nonKnightian, pre-crisis prices. In this analysis, while the amount of capital required to restore normal conditions would be very large, to offset the inefficient hoarding of resources, the impact of the provision of insurance, by removing for each agent the worst-case scenario, would be multiplied several times over. Essentially, Caballero called for a variation of the asset-side approach: a universal public insurance for distressed bank assets, at (or slightly below) pre-crisis values, offered to every market participant. 


\section{ROSSI Lessons from the Ongoing Crisis}

Jeffrey Sachs (2009) proposed to solve the dilemma of pricing toxic assets by building a bridge linking the two basic approaches. He wanted the public sector to buy distressed assets at face value (swapping them for government bonds for long enough for the storm to blow over), thus effectively cleaning up banks' balance sheets. What about moral hazard? Sachs's idea was the following: the government should receive warrants on each bank's capital, contingent on the eventual sale price of the swapped assets; if the assets' value, once the economy is back on track and the assets are liquid again (say, after a year), is at least equal to today's capital, the latter will absorb the possible loss and taxpayers will be safe; if not, taxpayers will sustain the residual loss and the bank will be then nationalised (for resale to private investors as soon as market conditions permit). Since the asset liquidation process is necessarily gradual, in the interim the government should have a sort of receivership, in order to make sure managers cannot strip off good assets.

What was actually done? The Financial Stability Plan for the US put forward by the Secretary of the Treasury Timothy Geithner in the Spring of 2009 combined the two approaches. In party, it returned to the original TARP intention of cleaning up the asset side of balance sheets, but in a new way: the government asked willing private investors to find a price for the distressed assets of a bank and to go halves with the public sector in buying them. The Plan also provided finance to private investors willing to purchase new securitized bank loans to small businesses and consumers. On top of that, a capital provisioning scheme was envisaged, whereby government could buy convertible preferred shares ("contingent equity") issued by capital-short banks, with some conditionality concerning such matters as dividends and acquisitions. The precondition was that these banks must have undergone a comprehensive "stress test" to ascertain all potential losses, due both to toxic "legacy" assets and to the economic downswing.

Other countries adopted measures classed in the two categories set forth above: 1) buying distressed assets (through a "special vehicle," a "bad bank" or whatever) or providing insurance on them; 2) recapitalizing banks.

The measures adopted have had a varying degree of success. World financial markets still exhibit a certain volatility and the risk of new liquidity shortages cannot be ruled out. My personal view on the issue of how to restore the credit market in circumstances like those experienced in 2007-08 rests on two points.

First, I think that in the countries most affected by the phenomenon of distressed assets in banks' balance sheets the two basic approaches should have been both pursued, although of course the mix between them could vary with national specificities. The main merit of Mr. Geithner's Plan was precisely that it pursued both. Relying only on the first would mean dangerous underestimation of insolvency risks. ${ }^{3}$ Relying only on recapitalization is subject to

\footnotetext{
${ }^{3}$ See Martin Wolf’s (2009) severe critique, "Why Obama’s new Tarp will fail to rescue the banks”
} 
Caballero's objection based on the peculiar state of uncertainty characterising the present crisis, which has blurred the boundary between illiquidity and insolvency: in countries where the "legacy" of past sins in banks' assets was heavy, it would have been preferable to complement recapitalization with some form of asset cleaning, better if in the form suggested by Jeffrey Sachs.

But the devil is always in the (missing) details, and this is my second point. What can determine the success or failure of any measure, is: are the incentives of all players right or wrong? In this connection, more than shareholders, the people to watch carefully are the managers of the banks.

It remains a general principle that a private agent is more suitable than a State bureaucrat for managing an enterprise efficiently. After the miserable show put on by so many bankers in some countries in the last few years, some people will find this hard to believe. But we must not mistake conflicts of interest and agency problems for lack of professional expertise.

Let's make two assumptions: i) that government wants to use the technical expertise of bank managers as much and as long as possible, though putting limits to their "greed”; ii) that managers are better informed than anyone else (shareholders and government in particular) on the true value of their assets (i.e. their likely post-crisis value); it may well be that at the onset of the crisis many bank managers had lost control over the content and valuation of most structured assets, but it's reasonable to assume that after a while they had become well aware of what was in their portfolios and able to attach a shadow price to each illiquid asset.

The two assumptions taken together pose a clear problem of incentive compatibility: government's support may be hindered by adverse managers' incentives. Here are a few textbook examples.

In such circumstances as those prevailing at the climax of the last crisis, Government's interest is to induce banks' managers to reveal the exact amount of distressed assets in the balance sheet of their bank. But:

a) If government offers to buy all their distressed assets at pre-specified prices, the managers' incentive is to sell only those assets whose estimated post-crisis value is less than the offered price, to extract a subsidy from the public intervention and to minimize their immediate personal reputation loss (which is the more serious the greater the amount revealed of toxic assets); as to the fate of the bank over the longer term, they are just buying time, hoping that in the end the overall public intervention will remedy the general situation and get them out of trouble altogether. From the public interest standpoint, the risk is wasting money and not getting the result.

b) Similar considerations apply to the case of an insurance scheme à la Caballero, even though in this case deductible-like schemes could be devised to reduce the adverse selection problem.

c) If government offers to recapitalize a bank, its managers have an interest in maximizing the public capital injection, provided that their freedom of manoeuvre is not too strictly 


\section{ROSSI Lessons from the Ongoing Crisis}

limited. This would go against the interest of private shareholders, who don't want to dilute their shares, but in the present circumstances their voice is obviously very feeble. The risk for the public purse is putting too much money into banks that may be less in need than others.

d) If government buys distressed assets and, at the same time, receives contingent warrants on the bank's capital, as in Sachs's idea, managers may want to minimize the probability of subsequent nationalisation, fearing to be fired in that event, so they may not sell the whole package of troubled assets, thus jeopardizing the recovery of the bank, again hoping that the systemic intervention will work and save them anyhow.

As these examples show, whatever the measure envisaged, its design is essential and must take into account, in particular, the incentives of banks' managers, in order to make them compatible with the government's objectives.

\section{Beyond the Emergency: Re-regulating the World Financial System}

To sum up: the global financial crisis of the century had several fathers and one mother. Among the fathers, perhaps the two most important were both on the macro side: the flood of liquidity that had inundated the world in the preceding fifteen years (whether it came from a saving glut in the emerging economies or from monetary policy mistakes in the advanced ones remains an open question); and an excessive propensity to consume in the US, fuelling unsustainable global payments imbalances.

The one and only mother of the crisis was the lack of effective financial regulation/supervision, particularly in the US.

The crisis is inducing strategic rethinking by both private operators and public regulatory and supervisory bodies. The crucial point is not to throw the baby out with the bath water. Most of the financial innovations of recent years were made for good reasons. For example, securitization and the "originate to distribute" model of banking were meant to allow the broader spreading of credit risk, in order to free banks' financial resources for further lending to a growing economy.

A different financial system must emerge from the difficult straits of today, not one that is restored to its archaic forms. A system in which intermediaries put up more of their own money (more equity capital) and take fewer risks, risks they can directly monitor, where they comply with well-defined and effective rules and are all, without exception, subject to a farreaching and internationally coordinated supervision. A system freed from the "idolatry of laissez-faire" still deep-rooted in the modern world, but not thrown back into obsolete technologies or permanently restrained by anachronistic "real socialism” bridles.

The dramatic events we have witnessed should teach us the importance of good analysis, good rules and their effective application for the full and fruitful exercise of free economic action, which is an indispensable engine of welfare. 


\section{References}

Adrian, T. and H.S.Shin (2008), Liquidity, Monetary Policy, and Financial Cycles, www.newyorkfed.org/research/current_issues/ci14-1.pdf .

Bernanke, B. (2005), The Global Saving Glut and the U.S. Current Account Deficit, www.federalreserve.gov/boarddocs/speeches/2005/200503102/.

Caballero, R. (2009), A Global Perspective on the Great Financial Insurance Run; Causes, Consequences, and Solutions, www.voxeu.org/index.php?q=node/2827.

Einaudi, L. (1931), Dei diversi significati del concetto di liberismo economico e dei suoi rapporti con quello del liberalismo in B. Croce and L. Einaudi (1988), Liberismo e liberalismo, Ricciardi: Milan and Naples. English translation in Luigi Einaudi (2006), Selected Economic Essays, Palgrave Macmillan: Basingstoke and New York, 75-76.

Sachs, J. (2009), A Strategy of Contingent Nationalisation, http://blogs.ft.com/ economistsforum/ 2009/02/ a-strategy-of-contingent-nationalisation/

Shleifer, A. (2005), Understanding Regulation, European Financial Management, 11, 439451.

Simmel, G. (1900), Philosophie des Geldes, Dunker\&Humblot, Lepzig,

Wolf, M. (2009), Why Obama's new Tarp will fail to rescue the banks" http://marketpipeline.blogspot.com/2009/02/why-obamas-new-tarp-will-fail-torescue.html 